\title{
KEEFEKTIFAN PENGGUNAAN MEDIA PEMBELAJARAN KARTU KUARTET DALAM PEMBELAJARAN KETERAMPILAN BERBICARA BAHASA JERMAN SISWA KELAS XI MA NEGERI 1 MAKASSAR
}

\author{
Zulfikar $^{1}$ dan Laelah Azizah ${ }^{2}$. \\ Fakultas Bahasa dan Sastra, Universitas Negeri Makassar \\ E-mail ${ }^{1}$ : zularsyadliebemathe@ gmail.com
}

\begin{abstract}
ABSTRAK
Tujuan dari penelitian ini ialah untuk mengetahui keefektifan media pembelajaran kuartet dalam meningkatkan kemampuan berbicara bahasa jerman siswa kelas XI IPA MAN 1 Makassar. Penelitian ini menggunakan quasi eksperimental design (eksperimental semu) dengan bentuk design non equivalent control group. Populasi dalam penelitian ini adalah kelas XI MAN 1 Makassar, yang terdiri dari 4 kelas dengan jumlah keseluruhan siswa adalah 100 siswa. Hasil penelitian menunjukkan bahwa penggunaan media pembelajaran kartu kuartet efektif dalam pembelajaran. Perolehan nilai post-test siswa, pada kelas eksperimen nilai terendah yaitu 50 dan nilai tertinggi 91 dengan nilai rata-rata 69,8, sedangkan pada kelas kontrol diperoleh nilai 8 untuk nilai terendah dan 67 untuk nilai tertinggi dengan nilai ratarata 38,1 . Hal tersebut dibuktikan dengan uji-t untuk melihat hasil akhir dari penelitian ini, masing-masing kelas dengan rumusyang sama. Hasilnya adalah $t_{\text {hitung }}$ kelas eksperimen $=$ 9,35 sementara $t_{\text {tabel }}=2,011$, jadi $\mathrm{t}_{\text {hitung }} \geq \mathrm{t}_{\text {tabel }}$ adalah 9,35 $>2,011$.
\end{abstract}

Kata Kunci: Media Kuartet, Kemampuan Berbicara, dan Bahasa Jerman

\begin{abstract}
The purpose of this study is to determine the effectiveness of quartet learning media in improving the ability to speak German class XI IPA MAN 1 Makassar. This research uses quasi experimental design (quasi experimental) with non equivalent control group design. The population in this study is class XI MAN 1 Makassar, which consists of 4 classes with the total number of students is 100 students. The results showed that the use of quartet card learning media is effective in learning. Obtaining the value of post-test students, the experimental class of the lowest score of 50 and the highest value of 91 with an average value of 69.8, while the control class obtained the value of 8 for the lowest value and 67 for the highest value with an average value of 38.1 . This is evidenced by the t-test to see the end result of this study, each class with the same formula. The result is $t_{\text {hitung }}$ of experiment group $=9,35$ then $t_{\text {tabel }}=2,011$, so $t_{\text {hitung }} \geq \mathrm{t}_{\text {tabel }}$ or 9,35 $>2,011$.
\end{abstract}

Keywords : Quartet Media, Speaking Skill, and German Language 


\section{PENDAHULUAN}

Di era globalisasi ini, keberadaan bahasa Indonesia sebagai Muttersprache atau bahasa ibu tidaklah cukup untuk menunjang strata kehidupan. Dibutuhkan bahasa asing sebagai alternatif pilihan yang sangat dianjurkan untuk diketahui oleh masyarakat. Bahasa asing sangat dibutuhkan untuk mengimbangi kemajuan teknologi dan komunikasi yang semakin cepat.

Bahasa Jerman adalah bahasa kedua terbesar di Eropa setelah bahasa Prancis. Mempelajari bahasa Jerman sebagai bahasa asing memiliki keunggulan tersendiri. Salah satunya karena Jerman adalah pusat pengkajian teknologi dan pendidikan yang cukup banyak menyita perhatian orang untuk berkunjung atau melanjutkan studi di negeri tersebut. Maka sebagai bekal sebelum ke sana, kita setidaknya harus paham dengan bahasa dan budaya mereka (Mantasiah, 2009).

Penelitian ini difokuskan pada keterampilan berbicara siswa. Berbicara merupakan perwujudan dari nilai-nilai sosial dan inte-lektual yang muncul dari elaborasi pemikiran mendalam yang telah dikonfrontasikan dalam otak. Dengan berbicara, transformasi gagasan akan lebih mudah.

Hasil pengamatan ketika penulis mengadakan PPL di MAN 1 Makassar pada tahun 2015 menunjukkan bahwa sebagian besar siswa mengalami kesulitan dalam keterampilan berbicara. Hal ini disebabkan praktik berbicara yang dilakukan siswa dalam proses belajar mengajar maupun di luar dari proses belajar mengajar masih kurang maksimal.

Kelemahan di atas juga diperkuat dengan beberapa penelitian tentang ke- mampuan berbicara siswa yang sangat kurang sebelum diberikan perlakuan atau treatment dalam proses pembelajaran, di antaranya adalah Ardiansyah (2014:34) ditunjukkan bahwa keterampilan berbicara bahasa Jerman siswa kelas XI SMA Negeri 11 Makassar termasuk dalam kategori cukup dengan hasil 63,46\%. Hasil penelitian yang dilakukan oleh Gaffar (2013:40) setahun sebelumnya ditunjukkan bahwa keterampilan berbicara bahasa Jerman siswa SMKN 6 Makassar termasuk dalam kategori kurang dengan hasil $47,00 \%$.

Salah satu alternatif untuk mengatasi masalah aktivitas dan hasil belajar bahasa Jerman yang rendah adalah menggunakan media pembelajaran permainan kartu kuartet. Permainan kartu kuartet cocok digunakan sebagai media pembelajaran karena selain bermain, siswa dapat belajar dengan suasana yang menyenangkan. Siswa dapat langsung mempraktikkan apa yang diajarkan guru sehingga akan memudahkan untuk mengingat materi pembelajaran. Permainan kuartet dapat membantu memudahkan siswa dalam meng-ingat dan mengimajinasikan kata-kata yang ada dalam kartu kuartet karena dilengkapi dengan gambar sehingga memudahkan siswa untuk berbicara menggunakan bahasa Jerman.

Keefektifan media pembelajaran kartu didukung oleh beberapa penelitian, diantaranya Lu'mu \& Mantasiah (2016), Na'ima (2014:2) menyatakan bahwa penggunaan media kartu kuartet dapat memotivasi siswa dan membuat siswa antusias dalam pembelajaran berbicara $(82,50 \%)$. Dari hasil penelitian Bertasari (2014:2) juga diperoleh hasil peningkatan 
aktivitas belajar berbicara siswa dengan rata-rata $(85,48 \%)$.

\section{KETERAMPILAN BERBICARA}

Keterampilan berbicara sebagai salah satu keterampilan dalam berbahasa merupakan keterampilan yang dibutuhkan oleh setiap orang untuk mengkomunikasikan pikirannya kepada orang lain. Menurut Tarigan (2013:3) "Berbicara adalah suatu keterampilan berbahasa yang berkembang pada kehidupan anak, yang hanya didahului oleh keterampilan menyimak, dan pada masa tersebutlah kemampuan berbicara atau berujar dipelajari.” Selanjutnya, Iskandarwassid dan Sunendar (2015:241) mengemukakan bahwa keterampilan berbicara pada haki-katnya merupakan keterampilan mere-produksi arus sistem bunyi artikulasi untuk menyampaikan kehendak, kebu-tuhan perasaan, dan keinginan kepada orang lain. Keterampilan ini juga didasari oleh kepercayaan diri untuk berbicara secara wajar, jujur, benar, dan bertanggungjawab dengan menghilangkan masalah psikologis seperti rasa malu, rendah diri, ketegangan, berat lidah, dan lain-lain.

Menurut Michael (dalam Satria 2013:32) terdapat beberapa hal yang harus diperhatikan sebelum memulai berbicara, yaitu "Bevor Sie zu sprechen beginnen überlegen Sie sich, wie das Gespräch verlaufen könnte und welche Wörter und Ausdrücke wahrscheinlich benötigen werden. Machen Sie sich Listen mit Redemitteln und Wortschatz zu den für Sie wichtigsten Standardsituationen ".

Berdasarkan uraian di atas, dapat disimpulkan bahwa keterampilan berbicara merupakan suatu keterampilan berbahasa ke dua setelah keterampilan mendengarkan dengan tujuan untuk menyampaikan pikiran dan perasaan kepada orang lain secara lisan dengan rasa percaya diri dan bertanggung jawab dengan apa yang diucapkannya. Selain itu, agar pembelajar dapat berbicara bahasa asing dengan lancar maka pembelajar harus mengulang-ulang kalimat yang diucapkannya sehingga lamakelamaan pembelajar akan memahami bagaimana pembentukan kalimat dalam bahasa asing tersebut dan akhimya dapat berbicara bahasa asing dengan lancar.

\section{MEDIA PEMBELAJARAN}

Proses belajar mengajar di sekolah akan mudah terasa jenuh jika tanpa media pembelajaran. Media pembelajaran diharapkan dapat menjadi perantara atau pengantar informasi belajar. Menurut Arsyad (2013:4) menguraikan pendapatnya bahwa "Media adalah komponen sumber belajar atau wahana fisik yang mengandung materi instruksional di lingkungan siswa yang dapat merangsang siswa untuk belajar."

Selanjutnya menurut Locatis \& Atkinson (dalam Satria, 2013:14) menjelaskan bahwa media merupakan wadah dari pesan yang ingin diteruskan oleh sumber atau penyalurnya kepada sasaran atau penerima pesan dengan tujuan untuk menciptakan proses belajar mengajar yang lebih aktif.

\section{MEDIA KARTU KUARTET}

Permainan kartu kuartet adalah permainan yang awalnya dikembangkan sebagai media pembelajaran kosakata oleh Dauviller dan Hillrech menjelaskan, kartu kuartet merupakan "salah satu jenis permainan di antara memo, domino, 
Quartette,

Listen-/Dialogspiele,

Reihenspiele, Kim-Spiele yang dapat dijadikan sebagai media pembelajaran kosakata" (dalam Agustika, 2011:26)

Selanjutnya menurut Agustika (2011:37) menguraikan bahwa permainan kartu kuartet adalah sejenis permainan kartu bergambar dengan judul gambar ditulis pada bagian atas kartu dan tulisannya diperbesar/ dipertebal. Judul ini merupakan tema dari kartu kuartet. Sedangkan di atas gambar terdapat kata-kata, yakni dua baris di bagian kanan dan dua baris di bagian kiri. Salah satu dari empat kata tersebut mengacu kepada gambar yang terdapat di bawah kata tersebut dan biasanya berwama lain atau digaris bawahi dari keempat kata yang terdapat pada bagian atas kartu".

Berdasarkan pendapat-pendapat tersebut, dapat disimpulkan bahwa permainan kartu kuartet merupakan permainan kartu yang terdiri dari sejumlah kartu bergambar dengan tema yang telah ditentukan. Pada setiap kartu terdapat judul dan sub judul untuk menjelaskan gambar tersebut. Pada setiap kartu terdapat judul di bagian tengah atas, sedangkan di atas gambar terdapat kata-kata yang merupakan sub tema, yakni dua baris di bagian kanan dan dua baris di bagian kiri. Salah satu dari empat kata tersebut mengacu kepada gambar yang terdapat di bawah kata tersebut dan biasanya berwama lain atau digaris bawahi dari keempat kata yang terdapat pada bagian atas kartu.

Langkah-langkah permainan kartu kuartet adalah dimulai dari guru membuka pelajaran pada hari itu dengan menyampaikan tujuan pembelajaran dan motivasi kepada siswa, kemudian guru menyampaikan materi pembelajaran kepada siswa. Guru memulai permainan dengan terlebih dahulu menyampaikan peraturan permainan. Guru membagi siswa menjadi delapan kelompok (disesuaikan dengan jumlah siswa). Setiap kelompok terdiri dari empat siswa. Jika jumlah siswa lebih maka guru bisa ikut berperan serta sebagai pemain tambahan.

Apabila kelompok telah terbentuk, maka salah seorang siswa di masing-masing kelompok diminta untuk mengocok kartu dan membagikannya kepada setiap siswa. Masing-masing siswa mendapatkan empat kartu. Sisa kartu yang tidak terpakai disimpan di tengah-tengah sebagai cangkulan; Jika peserta medapatkan empat kartu seri maka sudah terjadi kuartet dan permainan dimulai dari pemain tersebut dengan mengambil satu kartu cangkulan. Jika tidak ada yang seri di awal permainan, maka permainan dimulai dari nomor kartu yang terendah; Pemain tersebut bertanya pada pemain lain apakah dia mempunyai kartu yang memiliki sub judul yang sama dengan kartu yang dimilikinya. Permainan kemudian diberikan pada pemain berikutnya; Apabila terdapat pemain yang sudah memiliki empat kartu yang seri maka seri kartu tersebut disebut "kuartet" dan kemudian disisihkan/disimpan untuk dihitung pada akhir permainan; Permainan berakhir ketika delapan kuartet tersebut semuanya telah dikumpulkan oleh para pemain; Setelah permainan selesai, guru meminta siswa untuk membuat beberapa kalimat berdasarkan tema yang ada di dalam kartu kuartet yang sudah mereka dapatkan dan kemudian mempresentasikannya di depan kelas.

\section{METODE PENELITIAN}

Penelitian ini terdiri dari dua veriabel yakni variabel bebas dan variabel 
terikat. Penggunaan media pembelajaran kuartet sebagai variabel bebas (X), sedangkan kemampuan bahasa Jerman siswa kelas XI MAN 1 Makassar sebagai variabel terikat $(\mathrm{Y})$.

Penelitian ini menggunakan quasi eksperimental design (eksperimental semu) dengan bentuk design non equivalent control group. Seperti yang telah dipaparkan sebelumnya bahwa penelitian ini menggunakan dua variabel yaitu variabel bebas $(\mathrm{X})$ dan variabel terikat $(\mathrm{Y})$. Penggunaan media pembelajaran kuartet sebagai variabel bebas (X), sedangkan kemampuan berbicara bahasa Jerman siswa kelas XI MAN 1 Makassar sebagai variabel terikat (Y). Untuk memperjelas ruang lingkup penelitian ini maka digunakan definisi operasional variabel.

Seorang siswa dikatakan mampu berbicara dalam bahasa Jerman jika mereka mampu menceritakan gambaran umum tentang keluarga mereka, mampu mengungkapkan ujaran-ujaran untuk menanyakan keluarga, mampu mengungkapkan pekerjaan dari keluarga mereka.

Populasi dalam penelitian ini adalah kelas XI MAN 1 Makassar, yang terdiri dari 4 kelas dengan jumlah keseluruhan siswa adalah 100 siswa. Mengingat terbatasnya waktu yang digunakan untuk melakukan penelitian dengan jumlah kelas sebanyak empat kelas maka sampel total tidak digunakan pada penelitian ini. Penetapan sampel yang digunakan dalam penelitian ini adalah (sampel acak), kelas XI MIPA 4 sebagai kelas eksperimen yang terdiri atas 25 siswa dan kelas XI MIPA 3 sebagai kelas kontrol yang terdiri atas 25 siswa sebagai sampel penelitian. Sehingga total sampel berjumlah 50 siswa.

Pengumpulan data yang akan dilakukan dalam penelitian ini adalah dengan menggunakan sebuah instrumen yaitu tes kemampuan berbicara. Tes yang akan digunakan adalah sebuah berikut:

1. Tes Awal (Pretest) adalah tes yang diberikan kepada siswa di awal penelitian yang bertujuan untuk mengetahui tingkat kemampuan awal siswa terhadap materi yang akan diajarkan.

2. Tes Akhir (Posttest) adalah tes kemampuan yang diberikan kepada siswa setelah diajar dengan menggunakan media pembelajaran kuartet. Tes ini bertujuan untuk mengetahui bagaimana tingkat pencapaian siswa baik yang berada di kelas eksperimen yang menerapkan media pembelajaran kuartet maupun yang di kelas kontrol.

Data yang diperoleh dari test kemampuan membaca siswa dianalisis dengan menggunakan rumus uji-t. Sebelum dilakukan pengujian hipotesis terlebih dahulu dilakukan uji normalitas, dan uji homogenitas dengan menggunakan tabel Zscore dan chi kuadrat, sebelum menentukan uji normalitas data dan homogenitas maupun uji hipotesis terlebih dahulu tentukan nilai rata-rata (mean), simpangan baku, dan varian.

\section{HASIL DAN PEMBAHASAN}

\section{Analisis Statistik Deskriptif Pretest}

Penelitian ini diawali dengan pemberian pretest kepada kedua kelas, eksperimen maupun kontrol. Tes yang diberikan adalah dalam bentuk berbicara. Dari 25 siswa di kelas XI MIPA 4 sebagai 
kelas eksperimen, rerata (mean) hasil belajar siswa adalah 43,5. Nilai tertinggi adalah 75 dan nilai terendah adalah 17. Jika hasil tes kemampuan berbicara kelas eksperimen tersebut dikelompokkan kedalam 6 kategori

Berdasarkan nilai yang diperoleh pada pretest untuk kelas XI MIPA 3 sebagai kelas kontrol, dari 25 siswa didapatkan rerata (mean) hasil belajar siswa adalah 48,48 nilai tertiggi adalah 92 dan nilai terendah 17 Jika hasil tes keterampilan berbicara siswa kelas kontrol tersebut dikelompokkan dalam 6 kategori.

\section{Analisis Statistik Deskriptif Posttest}

Berdasarkan nilai yang diperoleh dari hasil post-test kelas XI MIPA 4 sebagai kelas eksperimen, rata-rata dari 25 siswa adalah 69,8 (nilai tertinggi adalah 92 dan terendah adalah 50). Dari hasil perhitungan diperoleh rentangan 6,83 dibulatkan menjadi 7 dan banyaknya kelas 6 .

Berdasarkan nilai yang diperoleh dari hasil post-test kelas XI MIPA 3 sebagai kelas kontrol rata-rata (mean) dari 25 siswa adalah 58,72 (nilai tertinggi adalah 67 dan terendah adalah 8). Dari hasil perhitungan diperoleh rentangan 9,83 dibulatkan menjadi 10 dan banyaknya kelas 6 .

\section{Uji Normalitas}

Sebelum melakukan pengujian hipotesis dengan menggunakan uji-t, terlebih dahulu dilakukan pengujian normalitas data dengan menggunakan tabel z-score dan chi-kuadrat.

Untuk pengujian normalitas data pre-test untuk kelas eksperimen, jumlah kelas interval ditetapkan $=6$ dan panjang kelas $=10$ dengan kriteria pengujian:

- Jika $\chi_{\text {hitung }}^{2}<\chi_{\text {tabel }}^{2}$ data normal

- Jika $\chi_{\text {hitung }}^{2}>\chi_{\text {tabel }}^{2}$ data tidak normal
Berdasarkan tabel z-score dan chikuadrat, maka uji normalitas data pre-test untuk kelas eksperimen dapat dihitung sebagai berikut:

$$
\begin{aligned}
& X^{2}=\sum \frac{\left(\mathbf{f}_{\mathbf{o}}-\mathbf{f}_{\mathbf{h}}\right)^{2}}{\mathbf{f}_{\mathbf{h}}} \\
& =\mathbf{- 1 0 7 . 5 7}
\end{aligned}
$$

Hasil tersebut dikonsultasikan dengan tabel harga chi-kuadrat dengan $\mathrm{dk}=$ (k-1). Pada tabel, banyaknya kelas interval adalah 6. Oleh karena itu $(\mathrm{k}-1)=6-1=5$. Pada tabel dengan $\mathrm{dk}=5$ tertera harga $\mathrm{x}^{2}$ $(\alpha)$ atau dengan taraf signifikansi $0,05=$ 11,07. Jadi harga Chi-kuadrat hitung lebih kecil daripada Chi-Kuadrat tabel, $\chi_{\text {hitung }}^{2}$ ($\mathbf{1 0 7 . 5 7})<\chi_{\text {tabel }}^{2}(11,07)$ atau $(-\mathbf{1 0 7 . 5 7}<$ 11,07). Oleh karena harga chi-kuadrat hitung lebih kecil daripada chi-kuadrat tabel, maka data pre-test siswa pada kelas eksperimen dinyatakan berdistribusi normal.

Untuk pengujian normalitas data pre-test untuk kelas kontrol, jumlah kelas interval ditetapkan $=6$ dan panjang kelas $=$ 13 dengan kriteriapengujian:

- Jika $\chi_{\text {hitung }}^{2}<\chi_{\text {tabel }}^{2}$ data normal

- Jika $\chi_{\text {hitung }}^{2}>\chi_{\text {tabel }}^{2}$ data tidak normal

Berdasarkan tabel z-score dan chikuadrat, maka uji normalitas data Pre-test untuk kelas kontrol dapat dihitung sebagai berikut:

$$
\begin{aligned}
\chi^{2} & =\sum \frac{\left(\mathbf{f}_{\mathbf{0}}-\mathbf{f}_{\mathbf{h}}\right)^{2}}{\mathbf{f}_{\mathbf{h}}} \\
& =\mathbf{- 1 1 8 . 4 5}
\end{aligned}
$$

Hasil tersebut dikonsultasikan dengan tabel harga chi-kuadrat dengan $\mathrm{dk}=$ (k-1). Pada tabel, banyaknya kelas interval adalah 6. Oleh karena itu $(\mathrm{k}-1)=6-1=5$. Pada tabel dengan $\mathrm{dk}=5$ tertera harga $\mathrm{x}^{2}$ $(\alpha)$ atau dengan taraf signifikansi $0,05=$ 11,07. Jadi harga chi-kuadrat hitung lebih 
kecil daripada chi-kuadrat tabel, $\chi_{\text {hitung }}^{2}$ ($\mathbf{1 1 8 . 4 5})<\chi_{\text {tabel }}^{2}(11,07)$ atau $(-\mathbf{1 1 8 . 4 5}<$ 11,07). Oleh karena harga chi-kuadrat hitung lebih kecil daripada chi-kuadrat tabel, maka data pre-test siswa pada kelas kontrol dinyatakan berdistribusi normal.

\section{Uji Homogenitas}

Uji homogenitas varians data menggunakan uji $\mathrm{F}$

$$
F_{\text {hitung }}=\frac{\text { varians terbesar }}{\text { varians terkecil }}
$$

Dengan kriteria pengujian sebagai berikut:

- Terima jika $F_{\text {hitung }}<\mathrm{F}_{\text {tabel }}$; dan

1. Pre-Test

- Tolak $\mathrm{H}_{0}$ jika $\mathrm{F}_{\text {hitung }}>\mathrm{F}_{\text {tabel. }}$

a) Varians Pre-test Eksperimen

$$
\begin{aligned}
& S^{2}=\frac{\sum f(X-\bar{x})^{2}}{n} \\
& =\frac{7600}{25} \\
& =304
\end{aligned}
$$

b) Varians Pre-test Kontrol

$\mathrm{S}^{2}=\frac{\sum f(X-\bar{x})^{2}}{n}$

$=\frac{7598.24}{25}$

$=303.93$

$F_{\text {hitung }}=\frac{303.93}{304}=0,999$, dibulatkan menjadi 1

Hasil tersebut dikonsultasikan dengan $\mathrm{F}$ tabel dengan $\mathrm{dk}=\mathrm{k}-1$, dimana (k) merupakan banyaknya jumlah kelas pada interval kelas uji normalitas sehingga diperoleh $\mathrm{db}_{\text {pembilang }}=(6-1=5)$ dan $\mathrm{db}_{\text {penyebut }}=(6-1=5)$ dengan taraf kesalahan $(\alpha)=0,05$ maka diperoleh $\mathrm{F}_{\text {tabel }}=5,050$ Ternyata $\mathrm{F}_{\text {hitung }}=1<$ $\mathrm{F}_{\text {tabel }}=5,050$, oleh karena $F_{\text {hitung lebih }}$ kecil dari $\mathrm{F}_{\text {tabel }}(1<5,050)$ maka $\mathrm{H}_{0}$ diterima, dengan demikian disimpulkan bahwa kedua sampel pre-test (eksperimen dan kontrol) memiliki varian yang sama atau homogen.
2. Post Test

a) Varians Post-test Eksperimen

$\mathrm{S}^{2}=\frac{\sum f(X-\bar{x})^{2}}{n}$

$=\frac{2352}{25}$

$=94.08$

b) Varians Post-test Kontrol

$$
\begin{aligned}
S^{2}= & \frac{\sum f(X-\bar{x})^{2}}{n} \\
& =\frac{5016}{25} \\
& =200.64
\end{aligned}
$$

$F_{\text {hitung }}=\frac{200.64}{94.08}=2,13$

Hasil tersebut dikonsultasikan dengan $\mathrm{F}$ tabel dengan $\mathrm{dk}=\mathrm{k}-1$, dimana (k) merupakan banyaknya jumlah kelas pada interval kelas uji normalitas sehingga diperoleh $\mathrm{db}_{\text {pembilang }}=(6-1=5)$ dan $\mathrm{db}_{\text {penyebut }}=(6-1=5)$ dengan taraf kesalahan $(\alpha)=0,05$ maka diperoleh $\mathrm{F}_{\text {tabel }}=5,050$ Ternyata $\mathrm{F}_{\text {hitung }}=2,13<$ $\mathrm{F}_{\text {tabel }}=5,050$, oleh karena $\mathrm{F}_{\text {hitung lebih }}$ kecil dari $\mathrm{F}_{\text {tabel }}(2,13<5,050)$ maka $\mathrm{H}_{0}$ diterima, dengan demikian disimpulkan bahwa kedua sampel post-test (eksperimen dan kontrol) memiliki varian yang sama atau homogen.

\section{Pengujian Hipotesis}

Berdasarkan hasil analisis statistik inferensial yang dilakukan terhadap hasil pre-test dan post-test siswa kelas XI MIPA 4 (kelas eksperimen) dan XI MIPA 3 (kelas kontrol) MA Negeri Makassar yang berjumlah 50 orang, untuk mengetahui ada tidaknya perbedaan tingkat keterampilan berbicara siswadalam bahasa Jerman khususnya pada kelas eksperimen, sebelum dan sesudah proses pembelajaran yang dilakukan di kelas, maka digunakan uji-t dengan rumus:

$\mathrm{t}=\frac{\bar{X}_{1}-\bar{X}_{2}}{\sqrt[s_{g a b}]{\left(\frac{1}{n_{1}}+\frac{1}{n_{2}}\right)}}$ 
Dimana:

$S_{g a b}=\sqrt{\frac{\left(n_{1}-1\right) S_{1}^{2}+\left(n_{2}-1\right) S_{2}^{2}}{n_{1}+n_{2}-2}}$

Dengan kriteria pengujian:

- $\quad$ Tolak $\mathrm{H}_{0}$, jika $\mathrm{t}_{\text {hitung, }}>\mathrm{t}_{\text {tabel, }}$

- $\quad$ Terima $\mathrm{H}_{1}$, jika $\mathrm{t}_{\text {hitung, }}>\mathrm{t}_{\text {tabel. }}$

Varians kelas ekperimen : 94.08

Varians kelas kontrol : 200.64

Mean kelas ekperimen : 69.8

Mean kelas kontrol : 38.1

- $\mathrm{S}_{\mathrm{gab}}=\sqrt{ } \frac{\left(n_{1}-1\right) S_{1}^{2}+\left(n_{2}-1\right) S_{2}^{2}}{n_{1}+n_{2}-2}$

$=\sqrt{ } \frac{(25-1) 94.08+(25-1) 200.64}{25+25-2}$

$=\sqrt{\frac{(24) 94.08+(24) 200.64}{48}}$

$=\sqrt{\frac{2257.92+4815.36}{48}}$

$=\sqrt{\frac{7073.28}{48}}$

$=\sqrt{ } 147.36$

$=12.14$

- $\mathbf{U j i}-\mathbf{t}$

$\mathrm{t}=\frac{\bar{X}_{1}-\bar{X}_{2}}{\sqrt[S]{\frac{1}{n_{1}}+\frac{1}{n_{2}}}}$

$=\frac{69.8-38.1}{\sqrt[12.14]{\frac{1}{25}+\frac{1}{25}}}$

$=\frac{31.7}{12.14}$

$=\frac{31.7}{12.14(0,28)}$

$=\frac{31.7}{3.39}$

$=9.35$

Hasil analisis data dengan menggunakan rumus uji- $\mathrm{t}$ di atas menunjukkan bahwa harga $\mathrm{t}$ hitung $=\mathbf{9 , 3 5}$. Harga $t$ hitung tersebut selanjutnya dibandingkan dengan harga $\mathrm{t}$ tabel dengan $\mathrm{dk}$ $=n_{1}+n_{2}-2=25+25-2=48$ pada taraf alpha 0,05 maka diperoleh $t_{t}=2,011$. Kriteria pengujian hipotesis yaitu tolak $\mathrm{H}_{0}$, jika $\mathrm{t}_{\mathrm{h}},>\mathrm{t}_{\mathrm{t}}$, dan terima $\mathrm{H}_{0}$, jika $\mathrm{t}_{\mathrm{h},}<\mathrm{t}_{\mathrm{t},}$. Berdasarkan analisis uji $\mathrm{t}$ maka diperoleh$$
\mathrm{t}_{\mathrm{h},}=9,35 \text { dan }_{\mathrm{t}}=
$$

2,011 maka $_{\mathrm{h}}=9,35>\mathrm{t}_{\mathrm{t}},=$

2,011. Dengan demikian $\mathrm{H}_{0}$ yang berbunyi: Tidak ada perbedaan signifikan antara keterampilan berbicara bahasa Jerman siswa yang diajar menggunakan media pembelajaran kartu kuartet dengan siswa yang tidak diajar menggunakan media pembelajaran kartu kuartet pada kelas XI MIPA MA Negeri 1 Makassar ditolak. Konsekuensi dari penolakan $\mathrm{H}_{0}$ maka $\mathrm{H}_{1}$ yang berbunyi: Ada perbedaan signifikan antara keterampilan berbicara bahasa Jerman siswa yang diajar dengan menggunakan media pembelajaran kartu kuartet dengan siswa yang tidak diajar menggunakan media pembelajaran kartu kuartet pada kelas XI MIPA MA Negeri 1 Makassar diterima. Penolakan $\mathrm{H}_{0}$ dan penerimaan $\mathrm{H}_{1}$ menunjukkan bahwa media pembelajaran kartu kuartet efektif dalam pembelajaran keterampilan berbicara bahasa Jerman siswa kelas XI MIPA MA Negeri 1 Makassar. Secara umum gambaran nilai siswa pada saat pretest dan posttest dapat dilihat pada uraian berikut.

a. Hasil Pretest Kelas Eksperimen dan Kontrol

Hasil pre-test menunjukkan bahwa nilai rata-rata (mean) untuk kelas eksperimen 43,5 dan kelas kontrol adalah 48,48 dalam keterampilan berbicara bahasa Jerman siswa kelas XI MIPA MA Negeri 1 Makassar, di mana jumlah skor perolehan untuk kelas eksperimen adalah 1075 dan kelas kontrol adalah 1207. Uji normalitas pada data pre-test pada kedua kelas menunjukkan bahwa kelas eksperimen dan kontrol memiliki chi-kuadrat hitung masing-masing lebih kecil dari chi-kuadrat tabel, $\chi_{\text {hitung }}<\chi_{\text {tabel }}$, dimana pre-test kelas eksperimen $(-107.57<11,07)$ dan pre- test kelas kontrol $(-118.45<11,07)$, sehingga 
distribusi data pre-test berasal dari populasi yang normal.

\section{Hasil Posttest Kelas Eksperimen dan Kontrol}

Berdasarkan hasil post-test, penggunaan media pembelajaran kartu kuartet berdampak positif pada peningkatan keterampilan berbicara siswa. Hal itu bisa dilihat dari perolehan nilai post-test siswa, di mana pada kelas eksperimen nilai terendah yaitu 50 dan nilai tertinggi 91 dengan nilai rata-rata 69,8 , sedangkan pada kelas kontrol diperoleh nilai 8 untuk nilai terendah dan 67 untuk nilai tertinggi dengan nilai rata-rata 38,1 .

Hasil analisis tersebut dilanjutkan dengan uji-t untuk melihat hasil akhir dari penelitian ini, masing-masing kelas dengan rumus yang sama. Hasilnya adalah $t_{\text {hitung }}$ kelas eksperimen $=9,35$ sementara $t_{\text {tabel }}$ $=2,011$, jadi $\mathrm{t}_{\text {hitung }} \geq \mathrm{t}_{\text {tabel }}$ adalah $9,35>2,011$.

Dengan demikian, $\mathrm{H}_{1}$ yang menyatakan bahwa Ada perbedaan signifikan antara keterampilan berbicara bahasa Jerman siswa yang diajar dengan menggunakan media pembelajaran kartu kuartet dengan siswa yang tidak diajar menggunakan media pembelajaran kartu kuartet pada kelas XI MIPA MA Negeri 1 Makassar dinyatakan diterima dan $\mathrm{H}_{0}$ yang menyatakan tidak ada perbedaan signifikan antara keterampilan berbicara bahasa Jerman siswa yang diajar menggunakan media pembelajaran kartu kuartet dengan siswa yang tidak diajar menggunakan media pembelajaran kartu kuartet pada kelas XI MIPA MA Negeri 1 Makassar dinyatakan ditolak. Oleh karena itu, dapat disimpulkan bahwa media pembelajaran kartu kuartet efektif dalam pembelajaran keterampilan berbicara siswa kelas XI
MIPA MA Negeri 1 Makassar. Berdasarkan hasil penelitian yang telah dikemukakan di atas, disimpulkan bahwa media pembelajaran kartu kuartetefektif digunakan dalam keterampilan berbicara bahasa Jerman siswa.

\section{KESIMPULAN}

Berdasarkan hasil analisis data yang telah diuraikan dapat disimpulkan bahwa penggunaan media pembelajaran kartu kuartet efektif dalam pembelajaran keterampilan berbicara bahasa Jerman siswa kelas XI MIPA MA Negeri 1 Makassar. Perolehan nilai post-test siswa, pada kelas eksperimen nilai terendah yaitu 50 dan nilai tertinggi 91 dengan nilai ratarata 69,8, sedangkan pada kelas kontrol diperoleh nilai 8 untuk nilai terendah dan 67 untuk nilai tertinggi dengan nilai ratarata 38,1 .

Hal tersebut dibuktikan dengan ujit untuk melihat hasil akhir dari penelitian ini, masing-masing kelas dengan rumusyang sama. Hasilnya adalah $t_{\text {hitung }}$ kelas eksperimen $=9,35$ sementara $t_{\text {tabel }}$ $=2,011$, jadi $t_{\text {hitung }} \geq \mathrm{t}_{\text {tabel }}$ adalah $9,35>2,011$ dengan taraf signifikansi 0,05 yang berarti bahwa ada peningkatan yang signifikan setelah penggunaan media pembelajaran kartu kuartet dalam pembelajaran, dimana $t_{h}$ lebih besar daripada $t_{t}$. Ini menunujukkan bahwa penggunaan media pembelajaran kartu kuartet efektif dalam keterampilan berbicara bahasa Jerman siswa kelas XI MIPA MA Negeri 1 Makassar.

\section{DAFTAR PUSTAKA}

Agustika, Ultari. 2011. Efektifitas Teknik Permainan Kuartet dalam Keterampilan Pembelajaran 
Kosakata Bahasa Jerman. Skripsi. Bandung: FPBS UPI

Aqib, Zainal. 2013. Model-Model, Media, dan Strategi Pembelajaran Kontekstual. Bandung: Vilama Widya

Ardiansyah, Sulabdi. 2014. Keterampilan Berbicara Siswa Kelas XI SMA Negeri 11 Makassar. Makassar: UNM

Arifin, Zainal. 2014. Penelitian Pendidikan. Bandung: PT Remaja Rosdakarya

Arsyad, Azhar. 2013. Media Pembelajaran. Jakarta: PT Raja Grafindo Jakarta Persada.

Baharuddin dan Esa Nur Wahyuni. 2015. Teori Belajar dan Pembelajaran. Yogyakarta: Ar-Ruzz Media

Bolton, Sybelle. 1995. Problem der Leistungsmessung Lernfortschrittstest in der Grundstufe. München: GoethoInstitut

Brown, H. Douglas. 2008. Prisip Pembelajaran dan Pengajaran Bahasa. Jakarta: Kedutaan Besar Amerika
Butzkam,W. 1989. Psycholinguistik des Fremdsprachunterrichts. Tubingen: France.

Chaer, Abdul dan Leonie Agustina. 2010. Sosiolinguistik Perkenalan Awal. Jakarta: Rineka Cipta.

Gaffar, Usman. 2013. Keterampilan Berbicara Bahasa Jerman Siswa SMKN 6 Makassar. Makassar: UNM.

Mantasiah, R. 2016. Kohesi Dalam Wacana Buku Kontakte Deutsch: Suatu Kajian Analisis Wacana (Cohesion In Discourses Of Kontakte Deutsch Book: a Study of Discourse Analysis). SAWERIGADING, 15(3), 336-348.

Taris, Lu'mu dan Mantasiah, R. 2016. Media Pembelajaran Anti Korupsi Berbasis Gender untuk Menanamkan Nilai-Nilai Kejujuran Sejak di SD. Jurnal Penelitian Pendidikan Insani, 19(2).

Steinig, Wolfgang; Huneke, Hans-Werner. 2007. Sprachdidaktik Deutsch. Eine Einführung. Berlin: Erick Schimdt Verlag 
Keefektifan Penggunaan Media Pembelajaran Kartu Kuartet dalam Pembelajaran Keterampilan Berbicara Bahasa Jerman Siswa Kelas XI MA Negeri 1 Makassar 